\title{
The Role of Schools and Educational Institutions in Helping Finding Career Pathways
}

\author{
Xiaoyan Wang \\ Melbourne Graduate School of Education, The University of Melbourne \\ Melbourne, Australia \\ Email:XIAOYANW5@student.unimelb.edu.au
}

\begin{abstract}
Students' career choosing is intricately related to family, school system, society, and country. In this age of intense competition, students need more effective and detailed career planning for their career goals and future based on social environment, their self-cognition, knowledge structure and more. The purpose of this essay is to explore the central role of schools and educational institutions in career education and helping students find their career pathways in Australia. Finding a career path can be divided into two stages: the first stage, the school helps students develop and explore their careers; the second stage, the students receive vocational training in educational institutions. School career development and exploration practice is the premise of the second stage, which is to promote middle school students to choose vocational education and training (VET) or pathway to university. Both of the options also play an essential role in helping different students find their career paths. The essay draws a conclusion that it is important to develop a parity of esteem between VET and academic education through school outreach and integrating the two.
\end{abstract}

Keywords: career exploration, career pathway, vocational education and training, academic education

\section{INTRODUCTION}

In these competitive times, choosing a decent career pathway is crucial to everyone. However, it can be challenging for students to decide which course and career path to take after graduation [1]. To be specific, many students tend to confuse which stream they should choose among various options such as business, art, science, technology, and humanities [1]. In this case, schools, especially secondary schools, play a central role in assisting students in identifying different post-graduation and career pathways and delivering career development and exploration for determining them [2]. A career path can be defined as a structured career planning method suitable for those who want to get a first job or improve their skills to achieve professional or personal goals [3]. School assistance in finding a career path means that school teachers, experts and professionals can provide students with career-related guidance. Including determining students' career interests, paying attention to education, information and training needs, and formulating personalized learning and action plans. The purpose is to let them understand their careers, set career goals, and prepare for future challenges [4].

\section{FIRST STAGE: CAREER EXPLORATION IN SCHOOLS}

In Australia, in addition to compulsory courses, there is a wide range of specialized or technical elective courses available to middle school students [2]. As there is no compulsory course in senior schools, students can take courses are interested in or related to their future career path [2]. As a result, school career development and interest exploration practice can be regarded as the first stage of assisting students to find their career pathways. If students want to make a successful transition from school to academic education, vocational education or employment, then the first stage is essential. In the first stage, the role of the school includes assessment and career advice, skill development, attention to individual student needs, mentoring, providing information about jobs and post-graduation courses and expanding social network [2] [5]. 


\subsection{Assessment and Counseling}

First of all, the starting point of the career exploration process in schools is to identify students' interests, aspirations, strengths, values, personalities, and preferences to assess which career path might be suitable for them in the future [4] [5]. Suppose these primary factors are not taken into account in the process of career planning and exploration. In that case, there is a big probability that students will not be well-positioned to find the right path and thus will have difficulty succeeding. Therefore, many self-assessment tools and career interest assessment tools can be introduced to students to explore their characteristics, form their perspective on career choices, plan their future career direction [5]. Furthermore, career counsellors in schools should interpret assessment results for students and provide career advice according to the results [5]. The most prevalent type of career advice activity in schools includes lectures from school career advisors, written material and handouts, and one-to-one consulting from their career advisors [6]. Students can also think about their own future career interests, career aspirations, career thoughts, career planning and perceived abilities [6].

\subsection{Skill Development}

Schools can be considered as a vocational hub dedicated to imparting knowledge and a range of skills to students so as to realistically plan for their futures [2] [4]. These knowledge and skills are needed by workers of the present and future, which can help students accumulate experience and prepare for the next step in achieving career goals [2]. In general, vocational skills can be divided into technical skills and non-technical skills, namely soft skills [7]. To be specific, technical skills are regarded as the essential vocational skills to meet the job requirements, which can be acquired through relevant professional programs or career readiness courses in secondary schools [8]. Soft skills are considered as non-technical skills, that is, some intangible personal qualities and attributes, including resilience, creativity, flexibility, responsibility, persistence, critical thinking, communication skills, social skills, information-seeking skills, negotiating skills, problem-solving skills, leadership, time management, self-advocacy and more [2] [7]. Some soft skills are in line with 21 st-century skills, which can be applied to almost all fields of work or continuing education and transformed into excellent work and task performance. For example, the ability to continuously learn and improve in the workplace, the ability to effectively and efficiently accept and use new technologies, the ability to build networks and manage partnerships, and the willingness to reflect, adjust and modify on time [7]. For young people, especially those from disadvantaged backgrounds, if they do not possess these technical and soft skills, they may be in a more disadvantaged position in the job search process in the future [2]. Fortunately, some of these skills can be acquired through school practice, including daily classroom instruction, volunteer activities, youth programs, work-study programs and community service [7].

\subsection{Attention to Individual Student Needs}

Students from different backgrounds tend to have different career development needs at different stages of their lives. The career advice and related supports provided by schools should be varied and tailored to meet better individual student needs [4]. It is suggested that the design of career development and exploration programs should not only be based on the school' s experience and guess about what students need, but also cultural differences and students' ideas should be involved in it because they know their own needs best [2] [6]. As a result, schools can develop individualized pathway plans to connect what students learn in schools with their career aspirations and help them with career preparation and further education plans [4]. To be specific, individualized pathway plans help instruct students on their learning and career exploration, build on their strengths and match their degrees and abilities with their career goals [4]. For instance, more systematic and theoretical knowledge is needed to enter specific fields, such as medical science, academia, education and political circles, so students must choose university pathways. Moreover, individualized pathway plans can help schools inform more equity and diversity considerations [9]. For specific groups of students, including indigenous students, disabled students, students with low socioeconomic status (SES), and young people from the non-English background, their needs should also be valued and addressed so that they can know what their values and competencies are in the future career [6] [9].

\subsection{Mentoring}

Youth mentoring means that students establish a trusting, interactive, caring, empathetic, and long-lasting relationship with an experienced non-parental person aiming to provide the student with some related guidance, supports, and encouragement to obtain progress [10]. Mentoring relationship in schools is considered to positively impact students' behavioral, social-emotional, and academic performances [11]. Career-related mentoring is an essential aspect of youth mentoring in schools. To be specific, students in schools can be assigned to caring and responsible mentors to get supports, helps, guidance, related information and opportunities from their experienced mentors as students 
transition from youth to adulthood and workforce [10]. Career-related guidance in schools can include setting career goals, developing personalized academic and career path plans, developing career preparation skills and experiences, reviewing resumes and personal statements in terms of effectiveness and clarity, writing recommendation letters, conducting mock interviews, seeking internship opportunities, and obtaining campus resources and information, In order to enhance students' confidence and motivation in the future [10]. In addition to school teachers, career mentors can also be industry professionals, academic researchers, community members, alumni and local business people with rich working experience [9]. These mentors from different work and education backgrounds can provide young people with valuable ideas to help them understand the actual situation in their work field. However, it is worth noting that schools need to ensure that mentors from outside are qualified and competent.

\subsection{Provision of Information about Various Pathways}

Young people need access to appropriate information about further education and career pathways, which can match their skills, abilities, interests and situation. There are eight sources of pathway information: parents and other adult relatives; teachers; career advisors; siblings and friends; printed materials; audiovisual materials; and people engaged in jobs of interest [2]. Researches suggest that students' decision on the pathways is mainly based on the information at hand and advice from parents and teachers [1] [12]. As a result, schools as "proactive catalysts” [2], can play a resource role in presenting reliable, up-to-date, high-quality and fair information about career pathways to parents and others in the school system so that students and their parents can think about their future pathways. Relevant information on access includes available education and training options (i.e., academic education, vocational education, and school apprenticeship), differences between various learning options, internship opportunities, occupations (i.e., admission requirements and conditions, strengths and weaknesses, and prospects), labour market trends, salary levels, etc. [1] [12]. In addition, schools should provide parents and students with information conveniently and humanely, such as easy-to-understand pamphlets, easy-to-understand language, and appropriate communication methods. For example, some students from non-English backgrounds think that written guidance materials and handouts are more valuable than others, while indigenous students prefer to talk directly with career counsellors. Therefore, schools need to pay attention to more details in assisting students in order that students with different backgrounds can make informed and deliberate choices [1].

\subsection{Expansion of Social Networks}

When students form their educational and career aspirations and determining career pathways, they will be consciously or unconsciously influenced by their social networks, including suggestions from parents, supports from school teachers and peer influence [13]. For example, young people and their parents with high socioeconomic status (SES) tend to have high aspirations for a career and are more eager for decent and prestigious occupations [12]. Further, these students might gain access to some well-regarded job opportunities with the help of parents [2]. In contrast, those students from lower SES families have relatively limited resources available in their circumstances when finding a job [2] [14]. In this regard, schools can play a role in helping students expand their social networks. Generally, in a school setting, school teachers and peer groups can be critical informants in finding career pathways, and students can benefit from some good communication [14]. To be specific, students can have more opportunities to interact and share with peers and teachers regarding career thoughts and experiences [13]. Students can also communicate and learn from the broad school community members, such as parents, employers, and others outside of their families, through extracurricular and community activities held by schools [13]. These members from different background might become role models or supporters for learners or parents in young people's career development, and help students form and expand their effective social networks gradually.

\section{SECOND STAGE: THE ROLE OF VET AND ACADEMIC EDUCATION IN FINDING CAREER PATHWAYS}

After graduation, most students will engage in vocational education and practice courses or more academic education of theoretical study. Studying at VET or university can be seen as the second stage of a student's career path. Students can get more professional training or higher quality academic research at this stage and further strengthen their skills. However, there has been a lack of respect and imbalance between vocational education and academic education for a long time, which is a common problem in many countries. Specifically, VET is generally considered to have a lower reputation and social status than diploma education. VET is even described as "the pathway of student with poor academic performance or with low SES background " [15], but its contributions and functions have been primarily weakened. Both academic 
education and vocational education have their focus, pedagogies, learning style, achievement, strengths, form and management, and play significant roles in assisting students in finding career pathways.

On the one hand, while receiving vocational education and training in Australia, students can study a fully focused curriculum, develop workplace-specific skills and after graduation might engage in relevant work, such as hairdresser, cosmetician, joiner, weaver, plumber, gardening, maintenance worker, or mechanic [1]. It is undeniable that VET was once regarded as training workers for physical labour or some labour-intensive jobs, which results in its low reputation and popularity among some teachers, students and parents, especially in this age of meritocracy [1]. Fortunately, the mission of vocational education and training in Australia will now change [16]. Specifically, students receiving vet can enter a wide range of new fields and majors, such as health care, office work, technology industry, retail, business management, trade, etc. [16]. The most significant advantage of VET is that it can combine learning in a university environment with practical work experience in a specific industry [16]. Therefore, colleges and universities should further strengthen cooperation with relevant industries and enterprises to enhance students' employability better and provide graduates with multiple employment destinations [12] [17]. Moreover, in addition to cultivating technical skills, vocational education should also contribute to the overall development of students, including supporting them to enrich their knowledge, improve their literacy and cultivate critical and creative thinking [18]. So that students can be competitive in the global and knowledge economy and can deal with. As a result, the reputation and popularity of VET can be gradually improved, and it moves away from serving those students with poor academic performance or low SES background [1] [15]. Parents, students and teachers can note that VET is also meaningful in training talents for national development [12].

On the other hand, the path to university has been receiving attention [19]. Vocational education focuses on techniques and skills learning, while academic education pays more attention to theory research, problem analysis, logical reasoning and critical thinking development. As a result, when VET and high education are compared, academic education is more like to train minds, yet VET is perceived as hand training. If students desire to engage in some fields such as politics, management, education, law, science, technology or medicine, the pathway to university might be the only right and appropriate choice. Students attending universities can study some relatively open and theoretical courses to explore theories and hypotheses. However, some theories and hypotheses may not be entirely practical, or directly useful in real life, leading to graduates often lacking practical job skills [7] [20].
Hence, it is not appropriate that people think academic education is much better than VET in terms of training students, even if the breadth and depth of courses and knowledge learned in higher education is different from that of VET. In this regard, people should change their views on VET, eliminate stereotypes, and develop a parity of esteem between vocational education and pathway to university. From another point, attending universities is more like a long-term investment. Students can learn some theories in the university first and gradually accumulate practical experience in the work as time goes on. When the practical work experience is in harmony with the theory, graduates will get a sense of self-worth, get more core positions and higher salaries. Therefore, adopting a work-integrated learning strategy (WIL) is essential to improve college students' employability and combine theory with practice [21] [22].

\section{CONCLUSION}

In conclusion, schools, academic education and vocational education all play significant roles in assisting different students to find and determine their career pathways at different stages. Students in school can obtain career development and exploration by evaluating interests, understanding career-related information, developing skills, guiding, expanding social networks and making personalized path plans. Moreover, in order to better play the role of personnel training, it is necessary to realize the transformation and integration of academic education and vocational education and improve the connection with employment.

\section{REFERENCES}

[1] Hargreaves, J., and Osborne, K., Choosing VET: aspirations, intentions and choice. National Centre for Vocational Education Research (NCVER). 2017.

[2] Patton, W., and McMahon, M., Career Development Learning in School Systems, In: Career Development and Systems Theory, Career Development Series (Connecting Theory and Practice), Sense Publishers, Rotterdam, vol. 2, 2014.

[3] Charles, P. C., Understanding career development: a convergence of perspectives, Journal of Vocational Education \& Training, vol. 3, 1998, pp. 437-461. DOI: https://doi.org/10.1080/13636829800200053

[4] Mittendorf, F. K., Jochems, W., Meijers, F., and Brok, P. D., Differences and similarities in the use of the portfolio and personal development plan for career guidance in various vocational schools in the Netherlands, Journal of Vocational Education \& 
Training, vol. 60, 2008, pp. 75-91. DOI: https://doi.org/10.1080/13636820701828903

[5] Brown, S. D., and Lent, R. W., Career development and counseling: putting theory and research to work, Wiley, 2005.

[6] Hillman, K., and Australian Council for Educational Research (ACER) (Eds.). School careers advice well received by students, Research Developments, vol. 20, 2008.

[7] Jackson, D., and Hancock, P., Non-technical skills in undergraduate degrees in business: development and transfer, Education Research and Perspectives, vol. 37, 2010, pp. 52-84. DOI: https://search.informit.org/doi/10.3316/informit.08 6515441566698

[8] Dominic, O. A., and Kevin, M., South Sudan: stakeholders' views of technical and vocational education and training and a framework for action, Journal of Vocational Education and Training, vol. 67, 2015, pp. 169-186. DOI: https://doi.org/10.1080/13636820.2014.983954

[9] Hare, R., Plotting the course for success: an individualized mentoring plan for youth with disabilities, National Consortium on Leadership and Disability-Youth, Institute for Educational Leadership. 2008.

[10] DuBois, D. L., and Karcher, M. J. (Eds.), Youth mentoring: Theory, research, practice, Handbook of youth mentoring, Sage Publishing, 2005. DOI: https://doi.org/10.4135/9781412976664.n1

[11] Rhodes, J. E., A model of youth mentoring, In: DuBois, D. L., and Karcher, M. J. (Eds.), Handbook of youth mentoring, Sage, 2005. DOI: https://doi.org/10.4135/9781412976664.n3

[12] Billett, S., Choy, S., and Hodge, S., Enhancing the standing of vocational education and the occupations it serves: Australia, Journal of Vocational Education and Training, vol. 72, 2020, pp. 270-296. DOI: https://doi.org/10.1080/13636820.2020.1751247

[13] Gibbs, B. G., Erickson, L. D., Dufur, M. J., and Miles, A., Extracurricular associations and college enrolment, Social Science Research, vol. 50, 2015, pp. 367-381. DOI: https://doi.org/10.1016/j.ssresearch.2014.08.013
[14] Cuervo, H., Chesters, J., and Aberdeen, L., Post-school aspirations in regional Australia: an examination of the role of cultural and social capital, The Australian Educational Researcher, vol. 46, 2019, pp. 843-861. DOI: https://doi.org/10.1007/s13384-019-00305-7

[15] Polesel, J., Vocational education and training (VET) and young people: the pathway of the poor?, Education \& Training, vol. 52, 2010, pp. 415-426. DOI: https://doi.org/10.1108/00400911011058352

[16] Australian Government, Vocational education and training, 2020a.

[17] Polesel, J., Klatt, M., Blake, D., and Starr, K., Understanding the nature of school partnerships with business in delivery of vocational programmes in schools in Australia, Journal of Education and Work, vol. 30, 2017, pp. 283-298. DOI: https://doi.org/10.1080/13639080.2016.1165344

[18] Wheelahan, L., The future of Australian vocational education qualifications depends on a new social settlement, Journal of Education and Work, vol. 28, 2015, pp. 126-146. DOI: https://doi.org/10.1080/13639080.2014.1001333

[19] Polesel, J., Gillis, S., Suryani, A., Leahy, M., and Koh, S., The Australian senior certificates: after 50 years of reforms, Australian Educational Researcher, vol.3, $2020 . \quad$ DOI: https://doi.org/10.1007/s13384-020-00403-X

[20] Hemsley-Brown, J., and Foskett, N. H., Gambling in the careers lottery: a consumer approach to career choice?, Journal of Vocational Education \& Training, vol.3, 1999, pp. 421-435. DOI: https://doi.org/10.1080/13636829900200090

[21] Jackson, D., Applying academic selection criterion to work-integrated learning programmes: risk management or perpetuating inequality?, Teaching in Higher Education, vol. 25, 2018, pp. 98-115. DOI: https://doi.org/10.1080/13562517.2018.1541884

[22] Rampersad, G. C., Developing university-business cooperation through work-integrated learning, Technology Management, vol. 68, 2015, pp. 203-227. 